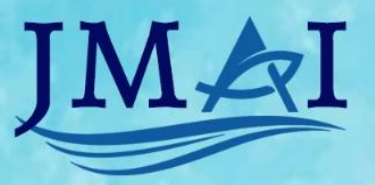

Jurnal Media Akwakultur

DN DON ESAA

https://journal.unram.ac.id/index.php/jmai/index. E-ISSN : 2798-0553

VOLUME 1, NOMOR 1, JUNI 2021

\title{
PERTUMBUHAN IKAN MAS DAN KIJING TAIWAN YANG DIPELIHARA PADA SISTEM RESIRKULASI
}

GROWTH OF GOLD FISH AND TAIWAN OYSTER CULTIVATED IN RECIRCULATION SYSTEM

Elizabeth M. Palinussa*), Jacqueline M.F. Sahetapy

Program Studi Budidaya Perairan Universitas Pattimura

Jalan Chr. Soplanit, Kampus Poka Ambon

Alamat korespondensi: isyepalinussa@gmail.com

\begin{abstract}
ABSTRAK
Kegiatan budidaya ikan secara intensif berarti melakukan pemeliharaan ikan dengan padat penebaran yang tinggi dan pemberian pakan buatan. Hal ini akan berdampak terhadap kualitas air yang buruk dan pertumbuhan dari organisme yang dibudidaya. Penelitian ini bertujuan untuk mengukur pertumbuhan ikan mas dan kijing taiwan yang dipelihara secara polikultur. Penelitian menggunakan Rancangan Acak Lengkap (RAL) yang terdiri dari padat tebar ikan mas (C. carpio) 30 individu dan berat awal (20 gr) kemudian padat tebar kijing taiwan (A. Woodiana) 0, 20, 40, 60 individu dengan ukuran berat awal 11 gr. Wadah percobaan yang digunakan adalah akurium dengan ukuran panjang $100 \mathrm{~cm}$ x lebar. Hasil penelitian menunjukkan adanya penambahan bobot tubuh ikan mas selama pengamatan berbeda unutuk setiap perlakuan. Dan pertumbuhan yang baik pada perlakuan dengan padat tebar yang banyak, berdasarkan hasil analisa ragam terjadi perbedaan nyata antar perlakuan $(\mathrm{P}<0,05)$. Untuk pertumbuhan kijing taiwan terlihat adanya penambahan bobot tubuh pada setiap minggu, dan pertumbuhan yang baik pada perlakuan padat terbar yang banyak. Berdasarkan hasil analisa ragam terjadi perbedaan nyata antar perlakuan $(\mathrm{P}<0,05)$. Kesimpulan dari penelitian ini adalah adanya pertumbuhan ikan mas dan kijing taiwan yang baik dengan padat penebaran yang tinggi.

Kata Kunci Pertumbuhan, Ikan Mas, Kijing Taiwan, Resirkulasi

Tracebility Tanggal diterima : 19 Mei 2021. Tanggal publikasi : 23 Juni 2021

Panduan Palinussa, E.M., \& Sahetapy, J.M.F. (2021). Pertumbuhan Ikan Mas Dan Kijing Kutipan (APPA $7^{\text {th }}$ ) Taiwan Yang Dipelihara Pada Sistem Resirkulasi. Jurnal Media Akuakultur Indonesia, 1 (1), 35-40. http://doi.org/10.29303/mediaakuakultur.v1i1.117
\end{abstract}




\section{PENDAHULUAN}

Kegiatan budidaya ikan secara intensif berarti melakukan pemeliharaan ikan dengan padat penebaran yang tinggi dan pemberian pakan buatan. Selain itu membutuhkan kuantitas air yang cukup besar. Hal ini akan berdampak terhadap kualitas air yang buruk dan pertumbuhan dari organisme yang dibudidaya.

Menurut Effendie (1978) pertumbuhan ikan adalah perubahan ukuran baik bobot, panjang maupun volume dalam jangka waktu tertentu. Faktor-faktor yang berpengaruh terhadap laju pertumbuhan adalah faktor internal yang meliputi keturunan, umur dan ketahanan terhadap penyakit, juga oleh faktor eksternal yang meliputi kualitas air, ketersediaan pakan dan ruang gerak hidup.

Ikan mas merupakan jenis ikan konsumsi air tawar yang sudah lama dibudidayakan, usaha pemeliharaan ikan mas makin berkembang, dengan ditemukannya teknologi pemeliharaan secara intensif. Dengan demikian kebutuhan benih meningkat (Cholik $d k k$. 2005). Budidaya ikan mas (Cyprinus carpio), dengan padat penebaran tinggi dan disertai pemberian pakan tambahan yang intensif, dapat mencemari perairan.

Kijing taiwan dikenal sebagai filter feeder, daya tahan hidupnya yang tinggi dan dalam jumlah yang berlimpah kijing dapat dimanfaatkan untuk mengatasi pencemaran perairan akibat polutan termasuk logam berat dengan demikian hewan ini dapat membantu dalam usaha penjernihan air, kijing dapat memanfaatkan sisa makanan yang tidak sempat dimakan ikan sewaktu diadakan pemberian makanan tambahan sertadapat sebagai Biofilter. Selain itu, kijing dapat dimanfaatkan sebagai pakan ternak, industri kancing, dan penghasil mutiara (Prihartini, 1999).

Kualitas air merupakan faktor penting dalam budidaya kijing taiwan karena diperlukan sebagai media hidup kijing taiwan. Beberapa parameter fisika dan kimia yang mempengaruhi hidup kijing; adalah suhu, oksigen terlarut, $\mathrm{pH}$, total suspended solids, bahan organik, unsur hara (Sime 2005).

Sistem resirkulasi dapat meminimalkan pergantian air dan menjaga kualitas air. Menurut Ilyas (2014), bahwa sistem resirkulasi merupakan sistem budidaya yang dapat menghemat air karena dapat memanfaatkan ulang air yang sudah digunakan melewati sebuah filter. Untuk mengatasi masalah yang dihadapi maka dilakukan budidaya ikan mas bersama kijing taiwan menggunakan sistem resirkulasi Penelitian ini bertujuan untuk mengukur pertumbuhan ikan mas dan kijing taiwan.

\section{METODE PENELITIAN}

\section{Prosedur Penelitian}

Alat yang digunakan yaitu akurium dengan ukuran panjang $100 \mathrm{~cm} \mathrm{x}$ lebar $50 \mathrm{~cm} \mathrm{x}$ tinggi $50 \mathrm{~cm}$ sebanyak 12 buah. Masing-masing akuarium dilengkapi aerasi dan sistem resirkulasi, 3 buah bak tandon, 3 buah pompa (kapasitas 28000 l/jam), pipapvc, jangka sorong. 
Bahan yang digunakan yaitu hewanuji yang digunakan adalah kijing taiwan (Anodonta woodiana) dengan ukuran beratawal, (11 gr) benih diperoleh dari hasil tangkapan di alam. Setiap akuarium pada perlakuan ditebar kijing taiwan (A.woodiana) dan ikan mas (Cyprinus carpio) berat awal (20 gr). Kemudian diadaptasikan pada lingkungan pemeliharaan beberapa hari. Selanjutnya dilakukan pemeliharaan selama dua bulan, tingkat pemberian pakan dengan biomasa (3-5 \%). Frekuensi pemberian 3 kali sehari.

Perlakuan sebagai berikut:

Perlakuan A : 0 kijing taiwan (A. woodiana) +30 individu ikan mas (C. carpio)

Perlakuan B : 20 kijing taiwan (A. woodiana) +30 individu ikan mas (C. carpio)

Perlakuan C : 40 kijing taiwan (A. woodiana) +30 individu ikan mas (C. carpio)

Perlakuan D : 60 kijing taiwan (A. woodiana) +30 individuikan mas (C. carpio)

\section{Parameter Penelitian}

Parameter yang diukur adalah pertumbuhan (GR) dengan menggunakan rumus Kasim et al., (2017), sebagai berikut:

$\mathrm{G}=\mathrm{Wt}-\mathrm{Wo}_{\mathrm{o}}$

Keterangan:

$\mathrm{G} \quad=$ Pertumbuhan mutlak rata-rata (gr)

Wt = Berat bibit pada akhir penelitian (gr)

Wo = Berat bibit pada awal penelitian (gr)

\section{Metode Analisis Data}

Penelitian ini menggunakan rancangan percobaan dengan rancangan acak lengkap (RAL) yang terdiri dari empat perlakuan dan tiga ulangan. Selanjutnya di analisis ragam (Anova) dengan menggunakan aplikasi SPSS.

\section{HASIL DAN PEMBAHASAN}

Hasil pertumbuhan dari ikan mas dapat dilihat pada Tabel 1, kemudian analisi ragam pada Table 2. Sedangkan pertumbuhan dari kijing taiwan dapat dilihat pada Tabel 3 dan alasis ragam pada Tabel 4 selama penelitian.

Tabel 1. Rata-Rata Laju Pertumbuhan Harian Ikan Mas Selama Penelitian

\begin{tabular}{ccccccc}
\hline & \multicolumn{5}{c}{ Harike- } \\
& $\mathbf{1 0}$ & $\mathbf{2 0}$ & $\mathbf{3 0}$ & $\mathbf{4 0}$ & $\mathbf{5 0}$ & $\mathbf{6 0}$ \\
\hline A & $0,459 \pm 0,36^{\mathrm{b}}$ & $0,210 \pm 0,07^{\mathrm{b}}$ & $0214 \pm 0,13^{\mathrm{b}}$ & $0,525 \pm 0,41^{\mathrm{b}}$ & $0,580 \pm 0,48^{\mathrm{b}}$ & $0,780 \pm 0.8^{\mathrm{b}}$ \\
B & $0,578 \pm 0,28^{\mathrm{ab}}$ & $0,417 \pm 0,19^{\mathrm{ab}}$ & $0,463 \pm 0,06^{\mathrm{ab}}$ & $0,568 \pm 0,21^{\mathrm{ab}}$ & $0,774 \pm 0,25^{\mathrm{ab}}$ & $0,761 \pm 0,10^{\mathrm{ab}}$ \\
C & $0,615 \pm 0,68^{\mathrm{ab}}$ & $0,504 \pm 0,35^{\mathrm{ab}}$ & $0,636, \pm 0,50^{\text {ab }}$ & $0,686 \pm 0,03^{\mathrm{ab}}$ & $0,796 \pm 0,02^{\mathrm{ab}}$ & $0,844 \pm 0,16^{\mathrm{ab}}$ \\
D $^{0,726, \pm 0.61^{\mathrm{a}}}$ & $0,740 \pm 0,18^{\mathrm{a}}$ & $0,767 \pm 0,06^{\mathrm{a}}$ & $0,787 \pm 0,07^{\mathrm{a}}$ & $0,835 \pm 0,09^{\mathrm{a}}$ & $0,884 \pm 0,09^{\mathrm{a}}$ \\
\hline
\end{tabular}


Tabel 2. Hasil Analisa Ragam Pertumbuhan ikan mas

\begin{tabular}{lccccc}
\hline & Jumlah kuadarat & Df & Kuadrattengah & F & Signifkan( P) \\
\hline Antar kelompok & 348747,792 & 3 & 116249,264 & 5,292 & 0,008 \\
Di dalam kelompok & 439315,167 & 20 & 21965,758 & & \\
Total & 788062,958 & 23 & & & \\
\hline
\end{tabular}

Tabel 3. Rata-Rata Laju Pertumbuhan Harian Kijing Taiwan Selama Penelitian

\begin{tabular}{ccccccc}
\hline \multicolumn{6}{c}{ Perlakuan Hari ke- } \\
\hline & $\mathbf{1 0}$ & $\mathbf{2 0}$ & $\mathbf{3 0}$ & $\mathbf{4 0}$ & $\mathbf{5 0}$ & $\mathbf{6 0}$ \\
\hline B & $0,335 \pm 0,28^{\text {a }}$ & $0,357 \pm 0,07^{\text {a }}$ & $0,424 \pm 0,32^{\text {a }}$ & $0,512 \pm 0,09^{\text {a }}$ & $0,540 \pm 0,10^{\mathrm{a}}$ & $0,612 \pm 0,11^{\mathrm{a}}$ \\
C & $0,592 \pm 0,57^{\mathrm{b}}$ & $0,641 \pm 0,11^{\mathrm{b}}$ & $0,665 \pm 0,10^{\mathrm{b}}$ & $0,689 \pm 0,10^{\mathrm{b}}$ & $0,727 \pm 0,12^{\mathrm{b}}$ & $0,764 \pm 0,09^{\mathrm{b}}$ \\
D & $0,633 \pm 0,27^{\mathrm{b}}$ & $0,737 \pm 0,08^{\mathrm{b}}$ & $0,762, \pm 0,06^{\mathrm{b}}$ & $0,778 \pm 0,13^{\mathrm{b}}$ & $0,786 \pm 0,20^{\mathrm{b}}$ & $0,792 \pm 0,18^{\mathrm{b}}$ \\
\hline
\end{tabular}

Tabel 4. Hasil Analisa Ragam Pertumbuhan Kijiang Taiwan

\begin{tabular}{lccccc}
\hline & Jumlah kuadarat & Df & Kuadrat tengah & F & Signifkan( P) \\
\hline Antar kelompok & 265009,333 & 2 & 132504,667 & 20,633 & 0,000 \\
Di dalam kelompok & 96328,667 & 15 & 6421,911 & & \\
Total & 361338,000 & 17 & & & \\
\hline
\end{tabular}

Berdasarkan hasil yang diperoleh pada Tabel 1. Adanya penambahan bobot tubuh selama pengamatan berbeda unutuk setiap perlakuan. Jadi tidak terjadi persaingan dalam pemanfaatan ruang atau makanan dari ikan mas atau juga dari kijing taiwan. Dan pertumbuhan yang baik pada perlakuan $\mathrm{D}$, berdasarkan hasil analisa ragam terjadi perbedaan nyata antar perlakuan $(\mathrm{P}<0,05)$ dapat dilihat pada Tabel 2 . Hal ini berarti prinsip pengelolaan air hasil buangan budidaya ikan tidak hanya untuk mempercepat proses oksidasi bahan organik, selanjutnya ditujukan untuk mendapatkan kualitas air yang layak bagi suatu kepentingan budidaya, kualitas air yang baik merupakan input lanjutan bagi ikan yang dipelihara, sehingga proses metabolisme meningkat dan menghasilkan energi yang diperolah untuk pemeliharaan dan pertumbuhan.

Pertumbuhan dapat dipengaruhi oleh makan, ruangan, suhu dan beberapa faktor lainnya (Effendie, 1978). Sedangkan Wilburn dan Owan (1964) menyatakan bahwa pertumbuhan dipengaruhi oleh kualitas dan kuantitas pakan, umur dan lingkungan. Laju pertumbuhan dipengaruhi oleh makanan, suhu lingkungan, umur dan kandungan zat-zat hara dalam perairan (Hickling, 1971).

Pengamatan pertumbuhan Kijing taiwan penting dilakukan untuk mengetahui apakah hewan uji dapat dipelihara dalam skala laboratorium dengan sistem resirkulasi, pada akhirnya dapat dibudidayakan tanpa lagi bergantung dari alam. Pertumbuhan dapat 
dipengaruhi oleh makan, ruangan, suhu dan beberapa faktor lainnya (Effendie 1978). Sedangkan Wilburn dan Owan (1964) menyatakan bahwa pertumbuhan dipengaruhi oleh kualitas dan kuantitas pakan, umur dan lingkungan. Pennak (1953) mengatakan pertumbuhan yang nyata dari kijing dipengaruhi oleh beberapa faktor antara lain, temperatur, suplai makanan, arus air dan unsur kimia tertentu dalam air.

Berdasarkan dari data yang diperoleh pada Tabel 3 untuk pertumbuhan kijing taiwan terlihat adanya penambahan bobot tubuh pada setiap minggu, dan pertumbuhan yang baik pada perlakuan D. Berdasarkan hasil analisa ragam terjadi perbedaan nyata antar perlakuan $(\mathrm{P}<0,05)$ dapat dilihat pada Tabel 4 . Untuk pertumbuhan kijing taiwan menurut (Elyani 1990) kijing memiliki laju pertumbuhan yang lambat.

\section{KESIMPULAN}

Berdasarkan hasil penelitian dapat disimpulkan adanya pertumbuhan ikan mas dan kijing taiwan yang baik dengan padat penebaran yang tinggi

\section{DAFTAR PUSTAKA}

Cholik F, Jagataraya AG, Poernomo PR, Jauzi A. 2005. Akuakultur Tumpuan Harapan Masa Depan Bangsa.Jakarta: Masyarkat Perikanan Nusantara dengan Taman Akuarium Air Tawar Taman Mini Indonesia Indah.

Effendie, H. 2003.Telaah Kualitas Air, Bagi Pengelolaan Sumber Daya dan Lingkungan perairan. Penerbit Kanisius. Yogyakarta. 258 hal

Effendie, M. I. 1978. Metode Biologi Perikanan. Yayasan Dewi Sri. Bogor. 112 hal.

Elyani, E. 1990. Tingkat Pertumbuhan Kijing Taiwan (Anodonta woodiana. Lea). di Berbagai Habitat Perairan. [Skripsi]. Fakultas Perikanan, Institut Pertanian Bogor, Bogor. 63hal.

Gunadi B, Sudenda d, Khairuman.2008. Budidya Ikan Mas Secara Intensif. Jakarta: Agromedia Pustaka.

Hickling, C.V. 1971. Fish Culture. Faber and Faber. Queen Square. London. 317 hal.

Ilyas, AP., 2014. Evaluasi Pemanfaatan Fitoremediator Lemna Perpusilla sebagai Pakan Kombinasi dalam Pemberian Pakan Ikan Nila (Oreochromis niloticus) pada Sistem Resirkulasi. [Tesis]. Institut Pertanian Bogor.

Iskandar, F. 2002. Pengaruh Padat Penebaran Terhadap Keragaman Produksi Benih Gurame (Oshpronemus gouramy, Lac) yang di Pelihara dalam Sistem Resirkulasi. [Skripsi].. Fakultas Perikanan. Institut Pertanian Bogor. 36 hal.

Pennak, R.W. 1953. Fresh water Invertebrates of the United States. The Ronald Press Company. New Yrk. 769 pp.

Prihartini, W. 1999. Keragaman Jenis dan Ekobiologi Kerang Air Tawar Famili Unionidae (Molusca: Bivalva) di Beberapa Situ dan Kabupaten dan Kotamadya Bogor. [Thesis]. InstitutPertanian Bogor. Bogor. 94 hal. 
Sime, L. 2005. A literature Review of The Water Quality Requirements of the Freshwater Pearl Mussel (Margaritiferamargaritifera). and Related Freshwater Bivalves. http://www.blackwell-synergy.com.

Wilbur, K.M. and G. Owen . 1964. Growth Pages 211-237 in: K.m Wilbur and C. M. Yonge (eds). Physiology of Mollusca. Academic Press. New York. 